\title{
Customer Analysis: Does It Help to Improve Firm Performance? Research Results from Polish Insurance Market
}

\begin{abstract}
The paper attempts to answer the research question, whether conducting customer analysis improves firm performance. It presents results of research among Polish insurance agents. According to its findings, conducting customer analysis positively influences firm performance. Other factors that determine firm performance to a large extent are related to economies of scale and established competitive position (i.e. co-workers, low perception of risk related to other channels, agents' reputation). The use of dedicated CRM software does not influence firm performance.
\end{abstract}

Keywords: customer analysis, customer profitability, customer lifetime value, firm performance, reputation, insurance, CEE, Poland

Track: Marketing Theory and Strategy 


\section{Introduction}

Marketing performance measurement remains at the center of academics' and practitioners' attention (Clark, 2000; Kohli, Jaworski, 2009; Gupta, Zeithaml, 2006; Lehmann 2004; Kozielski 2008). Despite strong theoretical basis, the impact of marketing performance measurement on the firm performance is not clear. O'Sullivan and Abela show that ability to measure marketing performance has a significant impact on firm performance and marketing's stature within the firm (2007). Homburg, Artz and Wieseke found that the relationship of comprehensive marketing performance systems on company's performance is conditional. They also summarized the studies on general (not only marketing) performance systems. The studies show mixed and inconclusive results on relationship between comprehensive performance measurement systems and firm performance (Homburg, Artz, Wieseke, 2012).

A special role in marketing performance measurement is played by the metrics associated with customers, such as customer profitability and customer lifetime value (Dobiegała-Korona, 2011; Gupta, Lehmann, 2003; Tomczyk, 2012). Their knowledge allows customer portfolio segmentation and thus actions aimed at increasing the value of customer segments (e.g. customers of highest profitability, customers of negative profitability). Value of customer portfolio is also an important indicator as it may be the basis for company's valuation (Gupta \& Lehman, 2002).

Customer metrics are essential for gathering information and transforming it into knowledge on customer (Sobolewska, 2010), which is needed in the process of customer value management. The latter may be described as a managerial approach, in which customers are perceived as the company's asset, the value of which may be measured and increased through organization of the processes around customer relationships (Doligalski, 2013).

This paper attempts to contribute to the research area of effectiveness of marketing performance measurement. Its purpose is to identify the impact of conducting customer analysis on firm performance. Customer analysis is understood as the set of activities related to management of customer knowledge and measurement of customer metrics. The impact of conducting customer analysis on company's performance was compared against other factors affecting insurance agents' operational activities. The study was performed in 2012 among Polish insurance agents, in the sector typical for direct long-term relationships with customers (Tomczyk, 2013; 2014).

\section{Research Methodology}

Based on the qualitative exploration research (Individual Depth Interviews - IDIs) ${ }^{1}$, conducted between May and July 2012 on the sample of 8 micro-enterprises (purposive sampling), operating on insurance market in Poland (insurance agents), 14 features, linked to the firm performance, have been identified. It has been done on the base of respondents' direct declarations and in-context interviews interpretation (Tomczyk, 2014). To verify their relationship with the firm performance, between September and October 2012 a questionnaire survey has been conducted. The sample of the survey was 1,245 insurance agents from Poland. There were 275 questionnaires qualified for analysis. The criterion was the answer on every question, related to features identified in qualitative exploration research and questions related with firm performance. This kind of selection allowed to avoid the risk associated with the sample hidden diversity. All of the analyzed features are presented below.

\footnotetext{
${ }^{1}$ Source materials are available in Institute of Value Management at Warsaw School of Economics.
} 
Table 1.Analyzed features (model variables)

\begin{tabular}{|l|l|l|}
\hline Acronym & Dependent variable & Range of values \\
\hline FP & firm performance & $\langle-1,72 ; 1,98\rangle$ \\
\hline & Independent variables & \\
\hline CA & customer analysis & $<-2,13 ; 2,30\rangle$ \\
\hline ToC & type of customer & $\begin{array}{l}1-\text { only individual customers, } \\
\text { - only business customers }\end{array}$ \\
\hline EI & extraordinary incidents (fire, foods, etc.) & $1-5$ \\
\hline CBP & customer bargaining power & $1-5$ \\
\hline AR & agent's reputation & $1-5$ \\
\hline OSCR & other sales channel risk & $1-5$ \\
\hline PP & product profitability & $1-$ low; $5-$ high \\
\hline G & gender & $0-$ women, $1-$ men \\
\hline A & age & $20-70$ \\
\hline LoS & length of service (in years) & $0-35$ \\
\hline NoC & number of customers & $2-15000$ \\
\hline OW & offer width & $0-$ captive, 1 - independent \\
\hline CRM & use of CRM software & $1-$ none; $5-$ high \\
\hline CW & co-workers & $0-$ no, $1-$ yes \\
\hline
\end{tabular}

Firm performance (FP) is an aggregated variable, where the total 8 questions, measured on a Likert scale, have been reduced using exploratory factor analysis (principal axis method) to one dimension. Firm performance (FP) includes positions related to declared level of net income, net profit/loss, customer lifetime value and profitability in two perspectives: reference to the past and reference to other agents. The purpose of using these perspectives is to find the baselines for firm performance in absence of objective measures. Customer analysis (CA) is also an aggregated variable, where the total 8 questions, measured on a Likert scale, have been similarly reduced. Customer analysis includes positions related to activities of managing the knowledge on customers (gathering information on revenues, costs, recommendations and other values related to customers) as well as measurement of customer metrics (customer lifetime value, customer profitability).

The relationship between independent variables and firm performance has been verified by multiple regression methods (enter in the first step and backward in the second step). This composition of methods allows achieving the most economical model, with no insignificant predictors, eliminated in the order of p-value (from the highest to lowest).

Due to the type of the sample used for the quantitative study (auto-selective sampling) is not possible to obtain statistical generalization of the results to the whole micro-enterprises population, operating on insurance market and the level of significance refers only to the results of the sample. But it is possible to identify a situation in which the results of research presented can be applied by analytical generalization (Kvale, 2007), assuming that the insurance market (here: insurance agents) has the same characteristic like the whole microenterprises population, operating on other financial advisers' markets (Płonka, 2004). Because of the research method based on respondent's declarations (questionnaire interview and IDIs), the results of the study should also be treated carefully when evaluating. 


\section{Empirical Results}

Table 2 presents the summary of the second step model and table 3 depicts the results of the variance analysis.

Table 2. Second step model - summary

\begin{tabular}{|l|r|r|r|c|}
\hline Model & \multicolumn{1}{|c|}{$\mathrm{R}$} & R-squared & $\begin{array}{c}\text { Adjusted R- } \\
\text { squared }\end{array}$ & $\begin{array}{c}\text { The standard } \\
\text { error of the } \\
\text { estimate }\end{array}$ \\
\hline 1 &, 557 &, 310 &, 296 &, 83288453 \\
\hline
\end{tabular}

Table 3. Second step - Anova ${ }^{a}$

\begin{tabular}{|rl|r|r|r|r|l|}
\hline & Model & \multicolumn{1}{|c|}{$\begin{array}{c}\text { R- } \\
\text { squared }\end{array}$} & $\begin{array}{c}\text { Adjusted R- } \\
\text { squared }\end{array}$ & $\begin{array}{c}\text { The standard } \\
\text { error of the } \\
\text { estimate }\end{array}$ & Model \\
\hline 1 & Regression & 118,691 & 8 & 14,836 & 21,387 &, $000^{\mathrm{b}}$ \\
& Residual & 263,605 & 380 &, 694 & & \\
Total & 382,295 & 388 & & & \\
\hline
\end{tabular}

a. Dependent variable: firm performance

Adjusted R squared is 0,296 , which means that using eight predictors, the $30 \%$ of the variance of the dependent variable have been explained almost the same as in the first step, but without insignificant variables. The analysis of variance shows that the model is statistically significant, hence its predictability of the dependent variable is better than based on the mean. In table 4 the values of the coefficients are presented.

Table 4. Second step - coeficients ${ }^{\mathrm{a}}$

\begin{tabular}{|c|c|c|c|c|c|c|c|}
\hline \multirow[t]{2}{*}{ Model } & \multicolumn{2}{|c|}{$\begin{array}{c}\text { Unstandardized } \\
\text { Coefficients } \\
\end{array}$} & $\begin{array}{c}\text { Standardized } \\
\text { Coefficients }\end{array}$ & \multirow[t]{2}{*}{$t$} & \multirow[t]{2}{*}{ Sig. } & \multicolumn{2}{|c|}{$\begin{array}{l}\text { Colineary } \\
\text { Statistics }\end{array}$} \\
\hline & $B$ & Std. Error & Beta & & & Tolerance & VIF \\
\hline 1 (Const.) &,- 891 & ,297 & & $-2,999$ & ,003 & & \\
\hline $\mathrm{CW}$ & ,311 & ,089 &, 152 & 3,510 & ,001 & ,973 & 1,027 \\
\hline AR & , 194 & ,042 & ,203 & 4,665 & ,000 & ,954 & 1,048 \\
\hline $\mathrm{CA}$ & , 158 & ,047 &, 155 & 3,362 & ,001 & ,855 & 1,169 \\
\hline PP & , 126 & ,038 &, 152 & 3,308 & ,001 & ,861 & 1,161 \\
\hline ToC & , 126 & ,039 &, 149 & 3,214 & ,001 & ,847 & 1,180 \\
\hline EI & ,094 & ,037 &, 113 & 2,520 & ,012 & ,894 & 1,118 \\
\hline OSCR &,- 201 & ,032 &,- 271 & $-6,193$ & ,000 & ,948 & 1,055 \\
\hline A &,- 008 & ,004 &,- 100 & $-2,277$ &, 023 & ,948 & 1,055 \\
\hline
\end{tabular}

a. Dependent variable: firm performance 
During the analysis process, no collinearity and heteroscedasticity (among the continuous variables) have been identified. Due to the applied method, the level of statistical significance has been changing. The statistically significant predictors are: co-workers $(\mathrm{CW})$, agent's reputation (AR), customer analysis (CA), product profitability (PP), type of customer (ToC), and extraordinary level of insurance incidents (fires, floods, etc. - EI), other sales channel risk (OSCR) and age (A). Mathematical formula that allows showing the scope of mutual determination and predicting potential changes as a result of their interaction is presented below:

\section{Firm Performance $=-0,891+0,311 \mathrm{CW}+0,194 \mathrm{AR}+$ 0,158 CA + 0,126 PP + 0,126 ToC $+0,094 \mathrm{EI}+(-0,201)$ OSCR + (-0,008) A}

The interpretation is difficult by the lack of natural units of measure (among the continuous variables). However, one can assume that if no variables are mentioned, the level of firm performance is $-0,891$. It changes according to B-value, while the level of the independent variable increases by one point. The variable with the highest B-values $(0,311)$ is co-workers $(\mathrm{CW})$. Changing this variable from " 0 " to " 1 " (from "working alone" to "working with co-workers") increases the firm performance by 0,311 . Variables with B-values between 0,1 and 0,2 are agent's reputation (AR), customer analysis (CA), product profitability (PP) and type of customer (ToC). The variable with B-values between 0 and 0,1 is extraordinary level of insurance incidents (fires, floods, etc. - EI). There are also two negative coefficients. They come with variables: other sales channel risk (OSCR) and age (A). When the perceived other sales channel risk grows, the firm performance decreases. Similarly, age of the agent decreases the firm performance by the factor of 0,008 for a year.

\section{Discussion}

The purpose of this paper was to identify the impact of conducting customer analysis on firm performance. The resulting regression equation shows that conducting customer analysis increases the firm performance by the factor of 0,158 . It is more than the degree to which the change from selling low to high margin insurance products affects the firm performance $(0,126)$. Similarly, conducting customer analysis allows higher improvement of performance than changing the customer profile from consumer to business customers $(0,126)$. The use of dedicated CRM software does not directly influence the firm performance.

Having co-workers exerts the most significant influence on firm performance. It increases the firm performance by the factor of 0,311 which can be explained with economies of scale. The next variable, which influences firm performance to a large extent, however with a negative sign, are the risks associated with other sales channels, presumably with the online direct sales. Their impact on the firm performance amounts to $(-0,201)$. Agent's reputation increases the firm performance by the factor of 0,194. All these variables are dependent on the previous periods, in other words: they are usually developed in the long run and may be treated as indicators of established competitive position. Moreover, they remain in a feedback relationship with firm performance. Higher firm performance may result in hiring new coworkers, advertising campaigns improving reputation and lower perception of risk related to direct sales channels.

The category of factors on which agents have no influence comprise extraordinary events (fires, floods, thefts, accidents, etc.) that occurred during the year preceding the survey. They can cause customers' greater willingness to enter into a contract of insurance. This factor increases the firm performance by 0,094. The last of the factors taken into 
consideration is age of the agent. According to the regression results, it decreases to a small extent the firm performance $(-0,008)$. Analysis of scatter plot does not reveal any relationships between these variable. Hence, it contradicts the circulating opinion that the most successful are middle-aged agents due to their perceived credibility.

The below mentioned factors turned out not to be significant predictors of firm performance: agent's gender, number of customers, length of service, customer bargaining power, and - already mentioned - the use of dedicated CRM software.

Discussing the research results, one should also mention its limitations. Due to the difficulty in obtaining answers for direct questions about firm performance, the survey questions concerned rather the comparison of financial measures to the prior year, as well as to competitors. In the first case the agents had quite precise knowledge, in the second - the evaluation was based on their assumptions. Total 8 questions on firm performance have been reduced using an exploratory factor analysis to one dimension. The method reduces the volatility of a one measure, however makes it impossible to formulate conclusions that the change in one variable leads to e.g. $10 \%$ change of the profit. It allows though to identify the impact of variables on the declared level of firm performance.

\section{References}

1. Clark B. (2000). Managerial Perceptions of Marketing Performance: Efficiency, Adaptability, Effectiveness and Satisfaction, Journal of Strategic Marketing, No. 8, 325.

2. Dobiegała-Korona B. (2011). Wycena klienta [Customer Valuation]. In Panfil M., Szablewski A. (Eds) Wycena przedsiębiorstwa. Od teorii do praktyki [Enterprise Valuation. From Theory To Practice]. (pp. 521-549). Poltext, Warszawa (in Polish).

3. Doligalski T. (2013), Internet $w$ zarzadzaniu wartościa klienta [Internet-based Customer Value Management]. (pp. 19) Oficyna Wydawnicza SGH, Warszawa (in Polish).

4. Gibbs G. (2007). Analyzing Qualitative Data, London, Great Britain, Sage Publications Ltd.

5. Gupta S., Lehmann D. (Winter 2003). Customers as Assets, Journal of Interactive Marketing, Vol. 17, No. 1, 9-24.

6. Gupta S., Zeithaml V. (November-December 2006). Customer Metrics and Their Impact on Financial Performance, "Marketing Science", Vol. 25, No. 6, 718-739.

7. Homburg Ch., Artz M., Wieseke J. (May 2012). Marketing Performance Measurement Systems: Does Comprehensiveness Really Improve Performance?, "Journal of Marketing", Vol. 76, No. 3, 56-77.

8. Kohli A., Jaworski B., Market Orientation: The Construct, Research Propositions and Managerial Implications, "Journal of Marketing", Vol. 54 (April 1990)

9. Kozielski R. (2008). Wskaźniki marketingowe [Marketing Metrics], Oficyna Wydawnicza, Kraków 2008 (in Polish).

10. Kumar V., Shah D. (November 2009). Expanding the Role of Marketing: From Customer Equity to market Capitalization, Journal of Marketing, Vol. 73, 119-136.

11. Kvale S. (2007). Doing Interviews, London, Great Britain, Sage Publications Ltd.

12. Lehmann D. (October 2004). Metrics for Making Marketing Matter, "Journal of Marketing", Vol. 68, 73-75. 
13. O'Sullivan D., Abela A.V. (April 2007), Marketing Performance Measurement Ability and Firm Performance. "Journal of Marketing", Vol. 71, No. 2, 79-93.

14. Płonka M. (2004). Marketing instytucji finansowych [Financial Institutions Marketing], Wydawnictwo Akademii Ekonomicznej w Krakowie, Kraków (in Polish).

15. Sobolewska S. (2010). Model zarządzania wiedzą o kliencie [Customer Knowledge Management Model]. In Dobiegała-Korona B. \& Doligalski T. (Eds.). Zarzqdzanie wartościq klienta. Pomiar I strategie [Customer Value Management. Measurement and Strategies]. (pp. 141-156) Poltext (in Polish).

16. Tomczyk P. (2012). Co to jest wartość klienta? [What is Customer Lifetime Value?]. Available at http://www.valuecomesfirst.pl/wartosc-klienta/ [access: 25.03.2014] (in Polish).

17. Tomczyk P. (2013). Zarządzanie wartością klienta a wyniki ekonomiczne przedsiębiorstwa na przykładzie branży ubezpieczeniowej. Analiza jakościowa [Customer Lifetime Value Management and Firm Performance. Case of Insurance Industry in Poland. Qualitative Analysis]., Manuscript Title. Unpublished manuscript.

18. Tomczyk P. (2014). Multi-Method Analysis. In Ghorbani A, Takhar A, (Eds). Market Research Methodologies: Qualitative and Multi-Method Approaches. Manuscript Title. Unpublished manuscript. 